\section{NưN Kastamonu Eğitim Dergisi Kastamonu Education Journal}

Eylül 2019 Cilt:27 Sayı:5

kefdergi.kastamonu.edu.tr
Başvuru Tarihi/Received: 03.14.2018

Kabul Tarihi/Accepted: 12.21 .2018

DOI: $10.24106 / 2801$.

\title{
Okul Öncesi Dönem Çocuklarının Anlattıkları Sürpriz Kutu Hikayeleri
}

\section{Surprise Box Stories Told by Preschool Children}

\section{Öz}

\author{
Nilay DEREOBALI ${ }^{1}$, Mihriban ÖZCAN ${ }^{2}$
}

Bu araştırma okul öncesi dönem çocuklarının yapılandırılmamış materyallerle anlattkları hikayelerin içeriğini incelemek için yapılmıştr. Çocukların anlatttkları hikayelerin içeriğinin incelenmesi amacıyla durum çalışması kullanılmıştr. Araştırmaya 36-66 ay grubundan 18 çocuk katılmıştır. Veri toplama aracı olarak içinde çeşitli yapılandırılmamış materyallerin bulunduğu "Sürpriz Kutu" kullanılmıştır. Veriler görüşme tekniği ile toplanmıştr. Araştırmaya katılan 18 çocuktan 11'inin hikayeyi bitiremediği ve bir hikaye örgüsü kurgulamadığı görülmüştür. Anlatılan hikayelerde yaş ile hikaye karmaşıkığı arasında bir ilişki olduğu saptanmıştır. Ayrıca aynı sürpriz kutu içeriği kullanmalarına rağmen çocuklar hikayelerini farklı bir tema etrafinda oluşturarak, kendi cinsiyetleriyle özdeşleşen hikaye içeriği anlatmışlardır.

Anahtar Kelimeler: Hikaye anlatımı, okul öncesi dönem, yapılandırılmamış materyal

\section{Abstract}

This research has been conducted to investigate the content of stories that preschool children have told with unstructured materials. A case study has been used to examine the contents of the stories the children told. A group of 18 children aged between 36-66 months has participated in the research. "Surprise Box" is used as a data collection tool in which various unstructured materials are stored. The data has been collected by interviewing technique. It has been observed that 11 of the 18 children who participated in the research could not finish the story and construct a story arc. It has been determined that there is a relationship between age and story complexity in the narrated stories. Despite using the same surprise box contents, the children have told the stories associated with their own genders, creating a story around a different theme.

Keywords: Early childhood, storytelling, unstructured material 


\section{Extended Abstract}

Purpose of the Research: The fact that the opportunities provided to children to create their own stories in the plans of the preschool teachers and during the day are insufficient, and the inability to create an appropriate educational environment for this has revealed to the necessity of this research. The purpose of this research is to examine the contents of the stories children has told with unstructured materials.

Research Model: A case study has been used in this research in which the stories told by preschool children have been studied in an in-depth and holistic approach. The data has been collected by interviewing technique.

The research has used a box called "Surprise Box" to create children's stories, in which there were unstructured materials. When selecting materials, attention has been paid to the fact that these materials were three-dimensional, unrestricted and they did not direct the children. There are yellow, green, white plastic cover, baby food scale, black photo film box, square piece of burlap cloth and white fabric, yellow satin ribbon, 2 standard-size wooden pins, 5 pebbles, origami bird made from white paper.

All children participated in the research have described the story using the same standard box content. The stories told by children have been recorded in writing by the researchers.

Discussion and Conclusion: In this research, the contents of stories in which children tell with unstructured (open-ended) materials have been examined. It has been observed that 11 of the 18 children who participated in the research could not finish the story and construct a story arc. Children have generally created stories by talking about them or assigning them a task.

Upon examining the contents of the stories told; it has been observed that the children in the 36-47 month group gave simple assignments to the objects given to them and included narratives that did not have an arc; the children in the 48-59 month group created stories from the events in their immediate vicinity and the children in the 60-66 month group arranged the events better and told stories where imagination was more dominant. This has indicated that there is a relationship between age and story complexity in the narrated stories.

In the stories told by the children in the research, almost all of the children have included different themes in their stories. It has been noted that the themes of the stories told children in the 36-47 and 48-59 month groups included the events they observed in their immediate vicinity or near-time events, while the children in the 60-66 month group moved away from their immediate surroundings and created events based on imagination. In addition, the stories seem to be concrete products in which the children transmit their inner world, experiences, culture and world perceptions. Upon examining the themes of the stories, it is observed that, despite using the same surprise box contents, all of the children told their stories by assigning different functions to the materials given to them and by constructing different event frames.

In the research, boys have used the themes of heroism, military service, racing and classic fairy tales in their stories; while the girls have included the themes of family, princess, environment and charity. Although the materials given to children to use story telling do not have clues about genders, the themes they include in the stories highlight the roles that gender roles attribute to women and men. In addition, the children have depicted the content of the story associated with their genders. 


\section{Giriş}

Erken çocukluk döneminde çocukların kendilerini ifade etmek için sık kullandıkları yöntemlerden biri hikayelerdir. Bu dönemde hikaye anlatma, kelime dağarcığının genişlemesi, dil ve düşünme becerilerinin gelişmesi, hayal gücünün zenginleşmesi, dili kurallarına uygun kullanabilme ve ifade edici dil becerilerinin gelişimi açısından önemli bir yere sahiptir (Boudreau'dan aktaran Akmeşe, 2015). Ifade gücünün ve sosyal etkileşimin zenginleştiği bu dönemde hikayeler çocukların kendilerini daha açık ve net bir şekilde ifade etmelerini sağlamaktadır. Çocuklara kendilerini ifade etme firsatı verildiğinde sınıf içi sosyal etkileşim, anlama ve dinleme becerileri gelişmekte böylece çocuklar ana diline ait dil yapılarını doğaçlama olarak geliştirmektedir (Yapıcı, 2004). Sözel anlat becerilerinin gelişimi için gerekli temellerin atıldığı okul öncesi dönem, bu becerilerin kazanılması açısından kritik bir dönemdir (Yazıcı, Sarıca, Aksu ve Yurdakul, 2012). Bu dönemde ebeveynler ve eğitimciler hikayelerle, çocukların sözel anlatım kapasitelerini desteklemelidir. Sözel anlatım becerilerini desteklemek için Türkçe etkinlikleri önemli bir yer tutmaktadır.

Okul öncesi eğitim programında Türkçe etkinlikleri farklı şekillerde uygulanmaktadır. Bu uygulamalar; tekerleme söyleme, parmak oyunu oynama, bilmece sorma, sohbet etme, resimli kitap okuma, etkileşimli ve paylaşımlı okuma, hikaye anlatma, taklit oyunları, dramatizasyon (canlandırma), hikaye tamamlama, hikaye oluşturma, hikayeyi tekrar anlatma, bir hikayeyi resimlendirme ve resimlerden yeni bir hikaye oluşturma gibi etkinliklerdir (MEB, 2013). Türkçe etkinliklerinde kullanılacak birçok teknik olmasına karşın okul öncesi öğretmenleri bu tekniklerden daha çok öğretmen merkezli teknikleri tercih etmektedir. Alışkan ve Güneyli (2016) okul öncesi öğretmenlerinin Türkçe etkinliklerine ilişkin görüşlerini belirlemek amacıyla yaptıkları çalışmada, öğretmenlerin bu etkinlikler sırasında en çok düz anlatımı kullandıklarını saptamışlardır. Bu durum çocukların kendi duygu ve düşüncelerini aktarmada sınırıııklara yol açmaktadır. Öğretmenler hikaye anlatım tekniklerini uygularken çocukların kendi hikayelerini oluşturmalarını göz ardı etmektedir. Türkçe etkinlikleri sadece öğretmenin hikaye anlatımıyla sınırlandııılmamalıdır. Çocukların kendilerinin başlattğı ya da doğaçlama olarak gelişen dil etkinlikleri en az öğretmenlerin başlatthğı ve sürdürdüğü etkinlikler kadar önemlidir (Alışkan ve Güneyli, 2016). Türkçe etkinliklerinde çocuklara pasif dinleyicilikten çok aktif anlatıcı rolü verilmesi, çocukların bilişsel açıdan da aktif olmalarını sağlamaktadır.

Bu araştırma bilişsel yönüyle Vygotsky'nin bilişsel gelişim kuramına dayanmaktadır. Vygotsky'e göre çocuğun dilini aktif olarak kullandığı ortamlarda düşünme becerileri de gelişmektedir. Öğretmenler çocuklara hikaye anlatımlarını sağlayacak etkinliklerle bilişsel kapasitelerini artırmalarına destek vermelidir. Çünkü hikaye anlatımı erken çocukluk döneminde gelişmeye başlayan pragmatik bir dil yeteneğidir (Vygotsky, 1978). Erken çocukluk döneminin kritik becerilerinden biri düşündüğünü aktarabilme becerisi yetişkinlerin verdiği firsatlarla gelişen yaşamsal bir beceridir.

Çocuklar üç yaşından itibaren günlük olayları birbirine bağlayarak basit düzeyde giriş, gelişme, sonuç bölümleri içeren hikayeler anlatabilmektedir (Fekonja-Peklaj, Marjanovič-Umek ve Kranjc, 2010). Sunulan ortamlar ve sağlanılan firsatlar çocukların düşünme becerilerini geliştirmelerinde ve yaşadığı olayları hikayeleştirmelerinde önem kazanmaktadır. Okul öncesi dönemde çocukların kendilerini anlatmalarına ne kadar çok olanak sağlanırsa, çocukların sözcük dağarcığı, akademik başarıları, iletişim becerileri de aynı oranda gelişme gösterecektir.

Yapılan araştırmalar doğrultusunda okul öncesi eğitim kurumlarında çocukların kendi hikayelerini oluşturmaları, Türkçe etkinlikleri kapsamında sıklıkla yer verilmesi gereken bir etkinliktir. Çocukların olaylara karşı farkıı bakış açıları, problem çözme becerileri kazanmaları, neden-sonuç ilişkisi kurmaları bu tip etkinlikler yoluyla geliştirilmektedir. Ancak okul öncesi öğretmenlerinin planlarında ve gün içerisinde çocukların kendi hikayelerini oluşturmalarına verdikleri firsatın yeterli olmaması, buna uygun eğitim ortamının oluşturulmaması (Gönen, Ünüvar, Bıçakçı, Koçyiğit, Yazııı, Orçan, Aslan, Güven, ve Özyürek, 2010) bu araştırmanın gerekliliğini ortaya çıkarmıştr. Çocukların yapılandııılmamış materyallerle anlattkkları hikayelerin içeriklerini incelemek bu araştırmanın amacını oluşturmaktadır.

\section{Araştirma Sorusu}

Okul öncesi eğitime devam eden 36-66 aylık çocuklara verilen standart materyallerle oluşturdukları hikayelerin içeriği nasıldır?

\section{Yöntem}

\section{Araştırma Modeli}

Okul öncesi dönem çocuklarının anlattkları hikayelerin derinlemesine ve bütüncül bir yaklaşımla incelendiği bu araştırmada durum çalışması kullanılmıştr. Durum çalışması, araştırmacının kontrol edemediği bir olguyu, nasıl ve neden sorularına odaklanarak derinlemesine incelemeye firsat veren bir desendir (Yıldırım \& Şimşek, 2016). Görüşme, 
durum çalışmalarında derinlemesine bilgi sahibi olmak için sıkça kullanılan bir yöntemdir. Bu araştırmada da görüşme tekniğiyle veri toplanmıştr. Böylelikle hem desen hem de desenin ön gördüğü veri toplama tekniği ve veri analiz yönte$\mathrm{mi}$, anlatılan hikayelerin içeriğini derinlemesine analiz edilmesine ve betimlenmesine olanak sağlamıştir.

\section{Çalışılan Durum}

Hikaye anlatımı, deneyimleri, düşünce ve duyguları ifade etmek için gerçek bir insani yoldur (Broström, 2002). Çocukların anlattıkları hikayelerin içeriği de çocukların duygu, düşünce ve deneyimlerin anlaşılmasına olanak sağlamaktadır. Çocuklar çevreden aldığı öğrenmelerini, deneyimlerini, yaşantılarını, dünyayı algılayış biçimlerini, bulunduğu yaş grubunun gelişim özelliklerini, yaşadığı coğrafyanın kültürünü hikaye içine aktarabilmektedir. Alanyazında ana dili değerlendirme çalışmaları incelendiğinde, dili değerlendirme için genellikle öyküleme yönteminin kullanıldığı ve bu çalışmalarda da resimli kitapların tercih edildiği görülmüştür (Küntay, 2002; Işıtan ve Turan, 2014; Marjanovič-Umek, Kranjc ve Fekonja, 2002). Bu araştırmada farklı olarak üç boyutlu ve sınırlandııımamış (açık uçlu) materyallerin kullanılmasına karar verilmiştir. Farklı yaş gruplarından çocukların anlatth̆̆ hikayeler bu çalışmanın durumunu oluşturmaktadır.

\section{Çalışma Grubu}

Araştırmanın çalışma grubunu İzmir il merkezinde yaşayan ve bağımsız bir anaokuluna devam eden farklı yaş gruplarından çocukların bulunduğu toplam 18 çocuk oluşturmaktadır. Çalışma okulu seçilirken tipik durum örneklemesi kullanılmıştr. Okulların fiziksel durumu baz alınarak bağımsız anaokulu tercih edilmiştir. Özel okulların uyarıcı niteliğinin ve fiziksel koşullarının farklı olması, Milli Eğitim Bakanlığı'na bağı ılkokul ve ortaokulları bünyesinde bulunan ana-sınıflarının da fiziki koşullarının yetersizliği, uygulanan müfredatta çocukların ilkokula hazırlığına önem veren masa başı etkinliklerine yoğun olarak yer vermesi nedeniyle bu okullar tercih edilmemiştir.

Tablo 1. Araştırmanın Çalışma Grubunun Ay Dağılımı.

\begin{tabular}{lccccccc}
\hline Yaş Grubu & \multicolumn{2}{c}{$36-47$} & Ay & \multicolumn{2}{c}{$48-59$} & Ay & \multicolumn{2}{c}{$60-66$ Ay } \\
\hline Cinsiyet & K & E & K & E & K & E \\
Çocuk Sayısı & 3 & 3 & & 3 & 3 & 3 & 3 \\
Toplam & \multicolumn{2}{c}{6} & \multicolumn{2}{c}{6} & \multicolumn{2}{c}{6} & \multicolumn{2}{c}{6} \\
\hline
\end{tabular}

Çalışma grubuna dahil edilecek çocuklar bağımsız anaokulundan 36-47 ay, 48-59 ay ve 60-66 ay gruplarından, her gruptan 3 kız ve 3 erkek olmak üzere toplamda 18 çocuk ölçüt örnekleme yöntemiyle ailelerin gönüllü katılımları esas alınarak seçilmiştir (Tablo 1).

\section{Veri Toplama Araçları}

Sürpriz Kutu ve Materyaller: Araştırmada çocukların hikayelerini oluşturmaları için kullanılacak olan materyaller seçilirken, üç boyutlu ve sınırlandırılmamış olmasına, yakın çevre içinde kolayca bulunabilir olmasına ve bu materyallerin çocukları yönlendirmemesine dikkat edilmiştir. Bu nedenle araştırmada çalışma grubunun kendi hikayelerini oluşturması için "Sürpriz Kutu" olarak adlandırılan, içinde açık uçlu materyallerin olduğu bir kutu kullanmıştr.

Sürpriz Kutu kenarları gri yansımalı, kapağı kırmızı olan küp şeklinde karton bir kutudur. Sürpriz kutunun içinde bulunan materyaller: $2 \mathrm{~cm}$ çapında sarı plastik kapak, $4 \mathrm{~cm}$ çapında yeşil plastik kapak, $1 \mathrm{~cm}$ çapında plastik beyaz kapak, bebek maması ölçeği, siyah fotoğraf filmi kutusu, kare şeklinde bir kenarı $10 \mathrm{~cm}$ olan keten kumaş parçası, kare şeklinde bir kenarı $10 \mathrm{~cm}$ olan beyaz kumaş parçası, $30 \mathrm{~cm}$ uzunluğunda $2 \mathrm{~cm}$ eninde sarı saten kurdele, 2 tane standart boyutta ahşap mandal, 5 tane çakıl taşı ve beyaz kağıttan yapılmış kuş figürüdür.

Görüşme Formu: Çocuklarla yapılacak görüşme sırasında kullanılmak üzere bir görüşme formu hazırlanmıştır. Bu form hazırlanırken görüşmenin 36-66 ay grubu çocuklarla yapılacağı ve bu ay gruplarının gelişim özellikleri göz önünde bulundurularak formda çeşitli yönergelere yer verilmiştir. Yönergelerle çocuklardan kutuyu açmaları, materyalleri incelemeleri ve bunlarla bir hikaye oluşturmaları istenmiştir. Görüşme formu esnek yapıdaki yönergelerden oluşmaktadır. Yönergeler verilirken belirli bir sıra izlemek yerine, çocuklarla kurulan diyaloğun yapısı dikkate alınmıştır.

\section{Veri Toplama Süreci}

Görüşmeler, okulda bulunan çocukların dikkatini dağıtmayacak ve ses olmayan boş bir odada bireysel olarak yapılmıştr. Her yaş grubundan çocuklar aynı standart kutu içeriğini kullanarak hikayesini oluşturmuştur. Çocuklarla çalışma yapmanın etik sorumlulukları göz önünde bulundurularak video ve ses kaydı ile hikaye verilerinin toplanmasına Milli 
Eğitim Müdürlüğü tarafindan onay verilmemesi nedeniyle çocukların anlattğı hikayeler araştırmacılar tarafindan yazı ile kayda alınmıştı. Bu durumda veri kaybını önlemek amacıyla, bir araştırmacı çocuklarla görüşme yaparken diğer araştırmacı çocukların görmeyeceği bir yerde oturarak, anlatılan hikayeyi yazı ile kayda almıştır.

Yapılan deneme çalışmasında çocukların hikayeleri başlatmada zorluk çektiği görülmüştür. Çocuğun hikayeye başlamasına yardımcı olması için ek materyal olarak kağıttan yapılan origami kuş figürü belirlenmiştir. Ayrıca ikinci araştırmacının anlatılan hikayeleri yazıyla kayda geçirirken, çocukların dikkatlerini dağıtmadığı ve kayıt sırasında sıkınt yaşanmadığı görülmüştür. Uygulama sürecinde 36-47 ay grubundan bir çocuk, hikaye anlatmayıp odadan gitmek istediği için araştırmadan çıkarılmıştır.

\section{Verilerin Analizi ve Yorumlanması}

Çocuklarla yapılan görüşmelerden elde edilen nitel veriler, çeşitli aşamalardan geçerek içerik analizi sürecine alınmıştır. Bu sürece başlarken ilk önce, kayda geçirilen yazılar düzenlenmiş ve veri bütünlüğü sağlanmıştr. Deşifre esnasında gizliliğe önem verilerek çocukların isimleri yerine 3E1, 3K2 gibi kodlar kullanılmıştı. Verilen kodlarda ilk karakter çocuğun yaşını, ikinci karakter çocuğun cinsiyetini, son karakter ise çocuğun sırasını belirtmektedir.

Verilerin kodlanması aşamasında ise, veriler araştırmacılar tarafindan birbirlerinden bağımsız şekilde kesintisiz olarak okunmuş, görüşme sorularının cevapları alanyazında var olan kodlarla eşleştirilerek her yaş grubunun ayrı ayrı taslak kod listesi oluşturulmuştur. Araştrmacılar bir araya gelerek önce taslak kod listelerini hazırlamış, daha sonra veri seti tekrar okunarak kod listesinin son hali hazırlanmıştr. Kod listesini son haline ulaşınca araşttrmacılar birlikte çalışarak temalar kararlaştırımıştır. Böylece yaş gruplarındaki temalar net olarak ortaya çıkmıştır. Daha sonra Microsoft Excel Çalışma Sayfası'nda kategoriler, analizde ve hikayenin bütününde ortaya çıkan temalar veri alıntılarıyla ilişkilendirilmişlerdir. Bununla, araştırmanın raporlaştırılma kısmında uygun alıntılar yapılması sağlanmış, bulguların açık ve net bir şekilde ortaya konulması, tanımlanması ve yorumlanması kolaylaşmıştır.

\section{Geçerlik ve Güvenirlik}

Araştırmanın yapıldığı okul, araştırmacının farklı uygulamalı çalışmalar için gittiği bir okul olup çocukları tanıyor olması çocukların yabancılaşma sorununu ortadan kaldırmıştır.

Çocukların anlattğı hikayeler araştırmacının biri tarafindan yazıya geçirildikten sonra diğer araştırmacının teyit etmesi sağlanmıştr.

Çocukların anlattı̆ı hikayeler yorum katılmadan olduğu gibi yazıya geçirilmiştir.

\section{Bulgular ve Tartışma}

Çocukların yapılandırılmamış materyallerle anlatıkları hikayelerin içeriklerini incelemek amacıyla yapılan araştırmada elde edilen bulgular tablolar ve doğrudan alıntılar şeklinde sunulmuş ve tartışımıştır.

Tablo 2. Hikaye Bölümlerinin Yaş Gruplarına Göre Dağılımı

\begin{tabular}{lccc}
\hline Ay Grubu & \multicolumn{3}{c}{ Hikayenin Bölümleri } \\
\cline { 2 - 4 } & $\begin{array}{c}\text { Hikayesinde giriş } \\
\text { bölümü olan çocuk } \\
\text { sayısı }\end{array}$ & $\begin{array}{c}\text { Hikayesinde gelişme } \\
\text { bölümü olan çocuk } \\
\text { sayısı }\end{array}$ & $\begin{array}{c}\text { Hikayesinde sonuç } \\
\text { bölümü olan çocuk } \\
\text { sayısı }\end{array}$ \\
\hline 36-47 Ay (38 Ay) & 5 & 5 & 1 \\
48-59 Ay (51 Ay) & 6 & 4 & 1 \\
60-66 Ay (64 AY) & 6 & 5 & 4 \\
Toplam & 17 & 14 & 6 \\
\hline
\end{tabular}

Çocukların anlattğı hikayelerin giriş ve gelişme bölümlerini tamamlamada yaşlara göre belirgin bir farkın olmadığı görülmüştür. Toplam 17 çocuğun anlatthkları hikayelerinde giriş ve gelişme bölümlerine yer verdiği fakat sadece 6 çocuğun hikayeyi sonlandırabildiği sonucuna ulaşılmıştır.

Örneğin; 4E1 kodlu çocuğun anlattğı hikaye:

"Bir zamanlar yarışta bir çocuk varmış... Yarış̧̧ı varmış. Çok mutluymuş ben kazancam [kazanacağım] 
demiş. Ötekisi başkaydı ben kazancam [kazanacağım] demiş... Ama yarışı kazanması için ateş yokmuş. Ama ateşi yakamadığı için şey olmuş. Çok kızgınmıș. Kızgın olduğu için sinirlenmiş... Kazanamamış. Kızmış tekrar. Sonra kazanamadığı için benim güzel bir fikrim var. Arabayl daha güçlü arabalara, daha güçlü ateş yaparsam, arabama daha hızlı gidersem yarışı kazanabilirim demiş. Ama yine kazanamamış. Bir daha denemiş kazanabilmiş."

Örnek incelendiğinde, hikayede giriş, gelişme ve sonuç kısımlarının olduğu görülmekte fakat tam bir hikaye kurgusunun olmadığı dikkati çekmektedir. Bu örnekte de görüldüğü gibi çocuklar genellikle materyalleri konuşturarak ya da onlara bir görev atfederek hikayelerini oluşturmuşlardır.

Özellikle yaş ortalaması 38 ay ve 51 ay olan çocukların arasında ortalama 13 aylık fark olmasına rağmen anlattkları hikayelerde bir son olmaması; çocukların sembolik oyun oynayabilecekleri ve kendi hikayelerini kurgulayacakları oyun ortamı sağlanmaması, yapılan hikaye etkinliklerinin hem yöntem hem de sayı bakımından sınırlı olduğunu, çocuklara kitaplar yönünden zengin bir çevrenin sunulmadığını ve kendi hikayelerini anlatma firsatı tanınmadığını düşündürmektedir. Erdoğan ve Akay (2015), yaptı̆ı̆ araştırmada okul öncesi eğitim sınıflarında öğretmenlerin etkileşimli okuma yerine hikaye etkinliklerinde etkileşimsiz okumayı daha çok tercih ettiklerini, bu durumun da çocukların dil gelişimini olumsuz etkilediği sonucuna ulaşmıştır. Bu araştırmaya benzer olarak Senechal (1997) ve Wiseman (2011), yaptikları çalışmalarda çocukların aktif olduğu hikaye etkinliklerinin dil gelişimlerini desteklediği ve onlara önemli öğrenme firsatları sunduğunu belirlemişlerdir. Alanyazında yapılan çalışmalar ışı̆̆ında hikaye etkinliklerinde çocuklardan çok öğretmenlerin aktif anlatıcı olması, çocukların hikaye anlatmalarının desteklenmemesi onların hikayelerle olan deneyimlerini kısıtladığı söylenebilir. Okul öncesi eğitim kurumlarında uygulanan hikaye etkinliklerinde etkileşimsiz okuma yapılması, çocukların kendilerini ifade etmelerine yeterli firsatın verilmemesi, anlatılan hikayeler üzerinde düşünmelerinin sağlanmaması onların dil gelişimlerini olumsuz yönde etkilemektedir (Dereobalı ve Özcan, 2018). Araştırmada edilen bulgulardan biri olan çocukların tam bir hikaye anlatmamaları, okul öncesi eğitim kurumlarında çocukların hikayelerle olan deneyimlerinin sınırlı tutulmuş olmasına, yapılan hikaye etkinliklerinde genellikle öğretmenin düz anlatımı tercih ediyor olmasına ya da çocukların hikaye anlatmalarını sağlayacak etkinliklerin düzenli olarak yer verilmemesi ile açıklanabilir.

Anlatılan hikayelerin içeriklerine bakıldığında çocukların farklı temalar üzerinden hikayelerini şekillendirdikleri görülmüştür. Bu temalar Tablo 3'te belirtilmiştir.

Tablo 3. Çocukların Anlattı̆ı Hikayelerin Temalarının Yaşlara Göre Dağılımı

\begin{tabular}{lccc}
\hline Ay Grubu & 36-47 Ay & 48-59 Ay & 60-66 Ay \\
\hline & Oyun & Oyun & Oyun \\
& Ölüm & Yarış & Kahramanlık \\
& Askerlik & Prenses & Klasik Masal \\
Hikayelerin Temaları & Aile & Çevre & Yardımlaşma \\
& Tema yok & Yaralanmak & Tema yok \\
& Tema yok & Tema yok & Tema yok \\
\hline
\end{tabular}

Araştırmada aynı yaş grubundaki çocukların hikayelerini anlatırken seçtikleri temaların belirli konularda yoğunlaşt̆ğı görülmüştür. 36-47 ay grubu çocuklar oyun, ölüm, askerlik, aile temalarına yer verirken, 48-59 ay grubu oyun, yarış, prenses, çevre ve yaralanma temalarına, 60-66 ay grubu ise oyun, kahramanlık, klasik masal ve yardımlaşma temalarına hikayelerinde yer vermişlerdir.

"Bir asker varmış. Etrafinda kuzular varmış. Kuzuların arasından su geçiyormuş. Askere şapka... Burada deniz varmış. Denizden geçemiyorlarmış... Karşıda hazine varmış... Asker koruyor kuzuları. Çobanları birisi dövmesin diye. Sonra oyun oynuyorlarmış." [3E3]

“... Başka ormanda dışarıda çöpleri çöpe atarlarmış. Bu da ormanın koruyucusu. Burada burada şurada ve de burada çöpler varmıs. Sihirli ormandaki küçük olan çöp. Beyaz olan kirli çöpleri olan ormanın beyaz çimleri. Çöpleri çöp kutusuna atmak için örtüsü." [4K2]

"Evvel zaman içinde kalbur saman içinde bir tane gemi varmış. Karada yüzmek istiyormuş ama taşların arasında kaybolmuş, sıkışmış. Çıkmak istiyormuş. Geriye doğru gidiyormuş ama çıkamıyormuş. Onun için bir insandan yardım istemiş. Karada bir tane insan varmış. "Yardım edebilir misiniz?" demiş. Geminin içindeki adam. O da demiş ki tabi ki yardım edebilirim. Onu çıkartmış taşların arasından. Ondan sonra o da kurtulmuş." [5K3]

Temalara bakıldığında günlük yaşamla ilişkili oldukları göze çarpmaktadır. 36-47 ay grubu ve 48-59 ay grubu çocuk- 
ların hikayelerinin temalarını daha çok yakın çevrelerinde gözlediği ya da yaşadığı olaylardan esinlenerek hikayeler anlattkları; 60-66 ay grubu çocukların ise yakın çevrelerinden uzaklaşıp hayal gücüne dayalı hikaye temaları kullandıkları görülmüştür. Bu durum gelişim basamaklarından biri olan 'yakından-uzağa.' ilkesi ile açıklanabilir (Kablan, 2011). Bu gelişim basamağı göz önünde bulundurulduğunda çocukların kendi hikayelerini anlatırken yaşantlarından örnekler verdikleri göze çarpmaktadır. Örneğin, 3E3 kodlu çocuğun yakın zamanda bir asker uğurlamasına tanık olduğu ve yaşadığı bu olaydan etkilenerek hikayesinde askerlik temasına yer verdiği belirlenmiştir. Ayrıca oyun teması her yaş grubunda ortak olarak kullanılan tema olmuştur. Çocukların hikayelerinde oyunu tema olarak kullanmaları, oyunun okul öncesi dönem çocuklarının hayatında önemli bir rol oynadığını, çocukların her yaşta oyuna gereksinim duyduklarını ve oyunu bir ifade aracı olarak kullandıklarını göstermektedir (Murphy, 2009).

Araştırmada 36-47 ay grubunda bulunan çocuklar, hikaye anlatmaları için kendilerine verilen nesnelerle gerçekleştirdiği küçük eylemleri söyleyip, bir olay örgüsü olmayan anlatımlara sıkça yer vermişlerdir. 48-59 ay grubunda bulunan çocukların daha çok yakın çevresinden yola çıkarak bir hikaye örgüsü içinde anlatımlarını sürdürdüğü, 60-66 ay grubunda bulunan çocukların ise, diğer gruplarda bulunan çocuklara göre daha iyi kurgulanmış, olayların daha iyi sıralandığı, hayal gücünün ön planda olduğu hikayeler anlattı̆ı belirlenmiştir. Yapılan bu çalışmada çocukların yaşları ile hikaye karmaşıklığı arasında bir ilişki olduğu söylenebilir. Umek, Kranjc ve Fekonja (2002), yaptıkları çalışmada 4 yaşındaki çocukların daha basit düzeyde tanımlamaların yer aldığı hikayeler anlatırken 6 yaş grubu çocukların daha karmaşık bir yapıya sahip olan uzun hikayeler anlattkklarını bulmuştur. Marjanovic Umek, Legnik Musek, Kranjc and Fekonja (2003), yaptkkları çalışmada düzenli bir şekilde kitap okunan çevrede büyüyen çocukların anlattkları hikayelerin içeriğinin zamanla daha karmaşık bir yapıya büründüğünü ve bu hikayelerinde klasik masallara benzer bir sonuç cümlesine yer verdiklerini belirtmişlerdir. Benzer şekilde yapılan birçok çalışmada da yaş ile hikaye karmaşıklığı arasında bir ilişki olduğu ve çocukların yaşları ilerledikçe anlattkları hikayelerin gerçek bir hikaye yapısına benzediği saptanmıştı (Broström, 2002; Shapiro ve Hudson, 1991).

\section{Tablo 4. Çocukların Cinsiyetlerine Göre Anlattıkları Hikayelerin Temaları}

\begin{tabular}{cc}
\hline E & K \\
\hline Kahramanlık & Aile \\
Yarış & Prenses \\
Askerlik & Çevre \\
Klasik Masal & Yardımlaşma \\
\hline
\end{tabular}

Çocukların anlattğı hikayelerde ortaya çıkan temalar, cinsiyet açısından değerlendirildiğinde; erkek çocukların kahramanlık, yarış, askerlik, klasik masal gibi temaları kullandığı; kız çocukların ise aile, prenses, çevre ve yardımlaşma temalarını kullandığı görülmüştür.

“...Sonra da bir adam onlara tuzak hazırlamış. Ondan sonrada polis gelmiş. Tuzak kuran adamı yakalamış. Sonra da tuzağl yok etmiş.” [5E1]

“...Doğum günü varmış. Kafedeymiş doğum günü. Sonra pasta gelmiş. Ondan sonra mumları üflemiş kız. Yanında arkadaşları varmış." [5K1]

Çocukların hikaye anlatmalarında kullanmaları için verilen materyallerde cinsiyete dair bir ipucu bulunmamasına rağmen, hikayelerini oluştururken seçtikleri temaların cinsiyetlere göre farklılık gösterdiği belirlenmiştir. Soyer (2009), yaptığı çalışmada hikayelerde yer alan kalıp yargıların toplumsal cinsiyet rollerine dayalı olduğunu ve bu kalıp yargıların çocuklar üzerinde etkisinin önemli olduğunu belirtmiştir. Köseler (2009) ise okul öncesi hikaye kitaplarında kadın ve erkek figürlerin toplumsal cinsiyet rollerine göre anlatıldığı ve buna uygun şekilde resmedildiği sonucuna ulaşmıştr. Gündüz Şentürk ve Dereobalı (2015), yaptıkları çalışmada resimli çocuk kitaplarında yer alan kadın ve erkeklere atfedilen mesleklerin, kişilik özelliklerinin, ilgi alanlarının toplumsal cinsiyet kalıp yargılarına dayalı olarak anlatıldığını bulmuşlardır. Benzer şekilde Güder ve Yıldız (2016) da aile içi yapıların çocukların toplumsal cinsiyet rollerine olan bakış açılarını doğrudan etkilediği sonucuna ulaşmışlardır. Alanyazında yapılan birçok çalışmada olduğu gibi bu çalışmada da çocuklar hikayelerini anlatırken toplumsal cinsiyet kalıp yargıları bulunduran hikayeler anlatmışlardır. Hikayelerde toplumsal cinsiyet kalıp yargılarını içeren öğeler olması çocukların farkında olmadan hikayelerinde kendi cinsiyetleriyle özdeşleşen temalara yer verdiklerini göstermektedir. Çocukların kendi hikayelerini oluştururken yakın çevrelerinden öğrendikleri yapıları kullanmaları toplumsal kalıp yargılarının dışına çıkmadan, onlara anlatılan hikayelerin içeriğinden, onlarla oynanan oyunlardan, anne-baba tutumlarından, yaşadıkları çevrede bulunan bireylerin cinsiyete yükledikleri rollerden ve çevresinden edindiği toplumsal kalıp yargılarından kaynaklandığı düşünülebilir.

Araştırmada çocukların hikaye anlatmaları için verilen sürpriz kutu içeriği, farklı büyüklükte sarı, yeşil, beyaz plas- 
tik kapak, bebek maması ölçeği, siyah fotoğraf filmi kutusu, keten kumaşı ve beyaz kumaş parçası, sarı saten kurdele, ahşap mandal, çakıl taşı ve kağıttan yapılmış origami kuş figüründen oluşmaktadır. Hikaye anlatmaları için aynı sürpriz kutu içeriği verilmesine rağmen çocukların materyallere farkı anlamlar yüklediği görülmüştür. Örneğin, kağıttan yapılmış origami kuş figürü hikayelerde uçak, gemi, böcek ve kuş olarak, sarı kurdele ise ip, su, yılan, yol, sihirli orman, köprü olarak yer almıştir.

\section{“Bir böcek varmiş. Okulda bir böcek. Gizli bir böcek." [3E1] \\ "Vapurdan geçiyorlarmış, kurdeleden geçiyorlarmış, taşlardan böyle buluk buluk diye denizaltından geçi- yorlarmış." [3K2] \\ "Bir tane yılan varmış. Yılan yuvaya gidiyormuş. Yuvada da tavşan varmış. Tavşan içeride uyuyormuş." [4E2]}

Çocuklar hikayelerini anlatırken kullandıkları materyallerin dağılımları ve motifleri şu şekildedir: 3 çocuk kutuyu hikayesine dahil edip genellikle ev olarak kullanmıştr. Kağıttan yapılmış origami kuşu, 9 çocuk hikayesinde uçak, gemi, böcek ya da kuş olarak kullanmıştr. Yeşil, beyaz, sarı kapağı 10 çocuk kullanmış ve genellikle kapak olarak hikayelerinde yer vermişlerdir. 15 çocuk hikaye anlatırken ahşap mandalın 1 tanesini, 9 çocuk ise her ikisini birden kullanmıştır. Her ikisini kullanan çocuklar genellikle tavşan, abi-kardeş, yarışçı gibi motiflerde kullanmışlardır. Beyaz kumaşı 9 çocuk hikayelerinde deniz, yatak, gelinlik, orman, elbise motifleri olarak kullanmıştr. Keten kumaşı ise toplamda 3 çocuk kullanmış olup 2'si tam olarak motifini vermemiş, 1 tanesi kirli orman olarak kullanmıştr. Sarı kurdele 13 çocuğun hikayesinde yol, ip, yılan, sınıf motifi olarak yer almıştır. 9 çocuk hikayelerinde mama ölçeğine; çekiç, firlatma aracı, kaşık motifleri olarak yer vermiştir. Taşı kullanan 7 çocuk, cüce, arkadaş, taş, çöp motifleri olarak kullanmıştr. Sürpriz kutu içinde bulunan 5 taştan genel olarak 3 taşın kullanıldığı gözlenmiştir. 16 çocuk film kutusunu ana karakterin kullandığı bir aksesuar olarak kullanmıştr. Pinpon topunu ise 9 çocuk; top ya da aksesuar motifleri olarak kullanmıştır. Bu bulgulardan yola çıkarak, verilen materyaller arasında çocuklar tarafindan en fazla kullanılan materyal film kutusu olup, bunu ahşap mandal, sarı kurdele ve taş izlemiştir. En az kullanılan materyallerin ise keten kumaşı ve kutu olduğu saptanmıştır. Çocukların materyallere farklı anlamlar yüklemiş olmalarında kendi yaşantılarının, hayal güçlerinin ve onlara okunan hikaye kitaplarının etkisi olduğu düşünülmektedir.

\section{Sonuçlar}

Bu araştırmada çocukların yapılandırılmamış (açık uçlu) materyallerle anlattıkları hikayelerin içerikleri incelenmiştir. Araştırmaya katılan 18 çocuktan 11'inin hikayeyi bitiremediği ve bir hikaye örgüsü kurgulamadığı görülmüştür. Çocuklar genel olarak materyalleri konuşturarak ya da onlara bir görev atfederek hikaye oluşturmuşlardır.

Anlatılan hikayelerin içeriğine bakıldığında; 36-47 ay grubunda bulunan çocukların kendilerine verilen nesnelere basit görevler atfedip bir hikaye kurgusu olmayan anlatımlara yer verdikleri, $48-59$ ay grubu çocukların yakın çevresindeki olaylardan yola çıkarak hikaye oluşturdukları, 60-66 ay grubu çocukların ise olayların daha iyi sıralandığı ve hayal gücünün baskın olduğu hikayeler anlattkları görülmüştür. Bu durum, yaş ile hikaye karmaşıklığı arasında bir ilişki olduğunu göstermiştir.

Araştırmada çocukların anlattı̆ı hikayelerde; çocukların hemen hepsi hikayelerinde farklı temalara yer vermişlerdir. 36-47 ve 48-59 ay grubu çocukların anlattkları hikayelerin temalarına bakıldığında yakın çevrelerinde gözlediği ya da yakın zamanda yaşadığı olayları içerdiği, 60-66 ay grubunda bulunan çocukların ise yakın çevrelerinden uzaklaşıp hayal gücüne dayalı olayları kurguladıkları dikkat çekmiştir. Buna ek olarak, çocukların anlattıkları hikayelerde "oyun" teması ortak tema olarak görülmüştür.

Araştırmada erkekler hikayelerinde kahramanlık, askerlik, yarış, klasik masal temalarına yer verirken; kızlar aile, prenses, çevre ve yardımlaşma temalarına yer vermişlerdir. Çocuklara hikaye anlatırken kullanmaları için verilen materyaller cinsiyete dair ipucu içermemesine rağmen hikayelerinde yer verdikleri temaları, toplumsal cinsiyet rollerinin kadın ve erkeğe atfettiği rollerden seçtikleri dikkat çekmektedir. Ayrıca çocuklar kendi cinsiyetleriyle özdeşleşen hikaye içeriği anlatmışlardır.

Araştırmada hikayeler çocukların iç dünyalarını, deneyimlerini, kültürlerini ve dünya algılarını aktardığı somut birer ürün olarak görünmektedir. Hikayelerin temalarına bakıldığında, aynı sürpriz kutu içeriğini kullandıkları halde çocukların hepsinin kendilerine verilen materyallere farklı işlevler atfettikleri ve farklı olay örgüsü kurgulayarak hikayelerini anlattikları görülmüştür. 


\section{5. Öneriler}

Alanyazında çocukların hikaye anlatma becerileri üzerine yapılan çalışmalar incelendiğinde Türkiye'de bu çalışmaların sınırlı sayıda olduğu görülmüştür. Gelecekte yapılacak olan araştırmalarda erken çocukluk döneminde bulunan çocukların hikaye oluşturma becerilerinin incelenmesi için farklı materyal ve yöntemlere yer verilmesi ve farklı sosyoekonomik düzeydeki ailelerin çocukları ile benzer bir çalışmanın yapılması önerilebilir.

İskandinav ülkelerinde yapılan bir projede çocuklar kendi hikayelerini oluşturmuş ve yetişkinler bu hikayeleri yazıya geçirerek başka ülkelere göndermiştir (Broström, 2002). Yapılan bu projenin çocukların anlatım becerilerine katkı sağladığı söylenebilir. Bu projede olduğu gibi ülkemizde de çocukların kendi hikayelerini anlatıp, öğretmenleri ya da anne-babaları tarafindan bu hikayelerin yazıya geçirilmesi ve başka şehirlerde veya ülkelerdeki okullara gönderilmesi şeklinde projeler yapılması, çocukların hikaye anlatım becerilerine katkı sağlayabilir ve bu konudaki farkındalığı arttırabilir.

Okul öncesi eğitim kurumlarında öğretmenlerin sınıflarında çocukların kendi hikayelerini anlatmaları için gerekli ortamı hazırlamaları, oyun oynayarak hikaye kurgulayacakları eğitim ortamını düzenlemeleri ve çocukların ifade becerilerini geliştirmeleri için desteklemeleri önerilebilir. Çocuklara konu ve tema bakımından çeşitli ve nitelikli hikayeler anlatılması, çocukların anlatılan bir hikayeye son yazması, bir konu etrafinda hikaye geliştirmelerinin sağlanması onların anlat becerilerini destekleyecek ve geliştirecektir.

Bunlara ek olarak hikaye etkinlikleri öğretmen merkezli olarak sınırlı kalmamalıdır. Çocukların resimli kitaplardan anlattkları hikayelerin yanı sıra sınıf içerisinde bulunan diğer materyalleri ve okul bahçesinde açık havada bulunan doğal ve açık uçlu malzemeleri kullanarak hikayeler yaratmaları için firsatlar verilmelidir.

Hikaye anlatmanın sadece Türkçe etkinlikleri kapsamında ele alınması çocukların hikayelerle geçirdikleri zamanın kısıtlanmasına neden olmaktadır. Bu nedenle, serbest oyun zamanı kapsamında yaratıcılığı destekleyen bir eğitim ortamı hazırlanarak, hikaye etkinliklerinin daha geniş bir zaman diliminde uygulanması çocukların anlatım becerilerinde daha yetkin olmalarını sağlayacaktır. Böylece çocukların alıcı ve ifade edici dil becerileri, hayal güçleri ve yaratıcılıkları gelişecek ve kendi özgün hikayelerini oluşturma becerileri desteklenecektir.

\section{Kaynakça}

Akmeşe, P. P. (2015). Çocuklarda öykülemenin gelişimi ve dilin değerlendirilmesinde kullanımı. Ankara Üniversitesi Eğitim Bilimleri Fakültesi Özel Eğitim Dergisi, 16, 293-305.

Alışkan, E. E., ve Güneyli, A. (2016). Okul öncesi öğretmenlerinin Türkçe dil etkinliklerine ilişkin görüşleri: Lefkoşa örneği. Ana Dili Eğitimi Dergisi, 4, 348-371.

Broström, S. (2002). Children tell stories. European Early Childhood Education Research Journal, 10, 85-97.

Dereobalı, N., ve Özcan, M. (2018). Erken çocukluk döneminde yapılandırılmamış materyallerle hikaye oluşturmanın önemi. Dil Dergisi, 169, 51-65.

Erdoğan, N. I., ve Akay, B. (2015). Okul öncesi eğitimde hikaye okuma ve öğretmen sorularının incelenmesi. Mehmet Akif Ersoy Üniversitesi Eğitim Fakültesi Dergisi, 1, 34-46.

Fekonja-Peklaj, U., Marjanovič-Umek, L., \& Kranjc, S. (2010). Children's storytelling: The effect of preschool and family environment. European Early Childhood Education Research Journal, 18, 55-73.

Gönen, M., Ünüvar, P., Bıçakçı, M., Koçyiğit, S., Yazıcı, Z., Orçan, M., Aslan, D., Güven, G., ve Özyürek, A. (2010). Okul öncesi eğitim öğretmenlerinin dil etkinliklerini uygulama biçimlerinin incelenmesi. Mehmet Akif Ersoy Üniversitesi Eğitim Fakültesi Dergisi, $19,23-40$.

Güder, S. Y., ve Yıldız, T. G. (2016). Okul öncesi dönemdeki çocukların toplumsal cinsiyet algılarında ailenin rolü. Hacettepe Üniversitesi Eğitim Fakültesi Dergisi, 31, 424-446.

Gündüz Şentürk, S., ve Dereobalı, N. (2015). Examination of the picture story books published for preschool children in terms of social gender streotype. Recep Efe, Irina Koleva, i̇sa Gürebal (Ed.). Developments in educational sciences (s. 541-560). Sofia: St. Kliment Ohridski University Press.

Işıtan, S., ve Turan, F. (2014). Çocuklarda dil gelişiminin değerlendirilmesinde bir anlat analizi yaklaşımı olarak öykü anlatımı. Journal of Educational Sciences \& Practices, 13, 105-124.

Kablan, Z. (2011). Öğrenme- öğretim ilke ve stratejileri. Öğretim ilke ve yöntemleri (Bölüm 4).

file:///C:/Users/busr/Downloads/C2.renme-retimlkeVeStratejileri.pdf

Köseler, F. (2009). Okul öncesi öykü ve masal kitaplarında toplumsal cinsiyet olgusu. Yüksek Lisans Tezi. Adnan Menderes Üniversitesi, Sosyal Bilimler Enstitüsü, Aydın.

Küntay, A. C. (2002). Development of the expression of indefiniteness: Presenting new referents in Turkish picture-series Stories. Discourse Processes, 33, 77-101. 
Marjanovic-Umek, L., Kranjc, S., \& Fekonja, U. (2002). Developmental levels of the child's storytelling. Education Resources Information Center. https://files.eric.ed.gov/fulltext/ED468907.pdf

M.E.B. (2013). Okul öncesi eğitim programı. Ankara: M.E.B. Basımevi.

Murphy, P. A. (2009). Oyun çocuğun gıdasıdır. (i. D. Erguvan Sarıoğlu, Çev.). İstanbul: Kaknüs Yayınları.

Senechal, M. (1997). The differential effect of storybook reading on preschoolers' acquisition of expressive and receptive vocabulary. Journal of Child Language, 24, 123-138.

Shapiro, L. R., \& Hudson, J. A. (1991). Tell me a make-believe story: Coherence and cohesion in young children's picture-elicited narratives. Developmental Psychology, 27, 960-974.

Soyer, A. Ç. (2009). Okul öncesi dönem çocuk hikâye kitapları: Stereotipler ve kimlikler. Mehmet Akif Ersoy Üniversitesi Sosyal Bilimler Enstitüsü Dergisi, 1, 13-27.

Umek, L. M., Fekonja, U., Kranjc, S., \& Musek, P. L. (2003). The impact of reading children's literature on language development in the preschool child. European Early Childhood Education Research Journal, 11, 125-135.

Vygotsky, L. S. (1978). Mind in society: The developmental of higher psychological processes. Cole, M., John-Steiner, V., Scribner, S., Souberman, E. (Ed.). Cambridge Massachusetts. London, England: Harvard University Press. http://ouleft.org/wp-content/ uploads/Vygotsky-Mind-in-Society.pdf

Wiseman, A. (2011). Interactive read alouds: Teachers and students constructing knowledge and literacy together. Early Childhood Education Journal, 38, 431-438.

Yapıcı, M. (2004). İlköğretim dil bilgisi konularının çocuğun bilişsel düzeyine uygunluğu. İlköğretim-Online, 3, 35-41.

Yazıcı, Z., Sarıca, E., Aksu, M., ve Yurdakul, Y. (2012). Okul öncesi eğitimde Türkçe'nin öğretimi. Культура народов Причерноморья. http://dspace.nbuv.gov.ua/bitstream/handle/123456789/55849/30-Zeliha.pdf?sequence=1

Yıldırım, A., ve Şimşek, H. (2016). Sosyal bilimlerde nitel araştırma yöntemleri. İstanbul: Seçkin Yayıncılık. 